\title{
A representação da homossexualidade no discurso espírita de Divaldo Franco ${ }^{1}$
}

\author{
Recebido em 06/04/2020, aprovado em 15/07/2020 \\ DOI: $10.30612 / m v t . v 7 i 12.11375$ \\ Francisco Jomário Pereira ${ }^{2}$
}

\section{RESUMO:}

Este artigo tem como objetivo analisar a representação da homossexualidade na religião espírita brasileira a partir dos discursos de Divaldo Pereira Franco, médium e intelectual que atualmente influencia a religião no país. Para tanto, utilizamos a Análise do Discurso como estratégia teórica e metodológica para analisar os discursos proferidos e registrados em diferentes arquivos. Observamos que as representaçóes construídas são baseadas na perspectiva cristã e científica, reconfiguradas pelos mecanismos discursivos, internos e externos, do próprio discurso. Ao constituir a estratégia discursiva, a mesma passará a atuar de forma que o autor / doutrina seja (des) responsabilizado pelo dizer punitivo que é construído em torno do sexo, sexualidade e homossexualidade, o que chamamos de pedagogização da (des) responsabilização. Isso leva à manutenção da lógica heterosexista de controle e repressão das sexualidades vistas como anormais e minoritárias.

Palavras-chave: Religião. Espiritismo. Homossexualidade

\section{The representation of homosexuality in the spiritist discourse of Divaldo Franco}

\begin{abstract}
:
This article aims to analyze the representation of homosexuality in the Brazilian spiritist religion based on the speeches of Divaldo Pereira Franco, medium and intellectual who currently influence religion in the country. For that, we use Discourse Analysis as a theoretical and methodological strategy to analyze the speeches given, and registered in different archives. It was observed that the constructed representations are based on the Christian and scientific perspective, reconfigured by the discursive mechanisms, internal and external, of the discourse itself. When constituting the discursive strategy, it will start to act in a way that the author/doctrine is (un)responsible for the punitive saying that is built around sex, sexuality and homosexuality, what we call the pedagogization of

1 O presente trabalho foi realizado com apoio da Coordenação de Aperfeiçoamento de Pessoal de Nível Superior - Brasil (CAPES) - Código de Financiamento 001.

2 Professor Doutor em Sociologia na Universidade Estadual da Paraíba, Departamento de Ciências Sociais.
\end{abstract}


(de) accountability. This leads to the maintenance of the heterosexist logic of control and repression of sexualities seen as abnormal and minority.

Keywords: Religion. Spiritism. Homosexuality.

\section{La representación de la homosexualidad en el discurso espiritista de Divaldo Franco}

\section{RESUMEN:}

Este artículo tiene como objetivo analizar la Representación de la homosexualidad en la religión espiritista brasilera a partir de los discursos de Divaldo Pereira Franco, médium e intelectual que actualmente influye la religión en el país. Para tanto, utilizamos el Análisis del Discurso como estrategia teórica y metodológica para analizar los discursos proferidos y registrados en diferentes archivos. Observamos que las representaciones construidas son basadas en la perspectiva cristiana y científica, reconfigurada por los mecanismos discursivos, internos y externos, del discurso mismo. Al constituir la estrategia discursiva, que actúa de forma que el autor / doctrina sea (des) responsable por el dictado punitivo que es construido alrededor del sexo, sexualidad y homosexualidad, lo que llamamos de pedagogización de la (des) responsabilización. Eso lleva a la mantención de la lógica heterosexista de control y represión de las sexualidades vistas como anormales y minoría.

Palabras-clave: Religión. Espiritismo. Homosexualidad.

\section{DELIMITAÇÕES TEÓRICAS E METODOLÓGICAS}

O Espiritismo é uma religião que tem ganhado adeptos na última década, já ultrapassa mais de 3 milhôes de fiéis autodeclarados e 18 milhôes de simpatizantes (IBGE. 2010). Corresponde a um grupo social diversificado e de expressão, sua composição é de maioria branca, escolarizados, nível superior, e de "classe média em processo de ascensão social cuja relação com a leitura e a instrução tem um forte acento de distinção" (LEWGOY, 2000, p. 55). Compondo o extrato que para além do poder econômico, tem a capacidade de influenciar a definição do que pode ser moralmente aceito.

A partir dessas informaçôes nos questionamos: quais as representações criadas e difundidas, sobre a homossexualidade, pelo discurso de Divaldo Pereira Franco? E de que forma são apreendidas e reproduzidas por outros doutrinadores e seguidores da doutrina espírita? As questóes levantadas surgem não apenas de uma intenção acadêmica, mas também pessoal, tendo em vista que sou homossexual e praticante do espiritismo. Explicitamos esse fato pois, Souza (2015) nos assessora na reflexão quanto a posição adotada pelo sociólogo ao estudar algo que lhe caro. As questôes postas nortearam o texto que se segue.

Devemos esclarecer que procedemos a análise da representação da homossexualidade no discurso espirita contemporâneo, a partir de uma corrente específica, que nasce dos discursos e obras do médium e intelectual espírita Divaldo Pereira Franco. Analisamos a partir de diferentes arquivos, seriam eles: obras escritas por intermédio de guias espirituais, palestras, e discursos proferidos com repercussão nacional. 
Observamos que as ideias de Divaldo Franco ajudaram a construir o que hoje tomamos por Doutrina Espírita, ou Religião Espírita no Brasil. Para além de Chico Xavier, Divaldo continuou peregrinando e divulgando a seu modo a Doutrina. Seus ideais encontram terreno fértil, mas isso não significa que encontre aprovação imediata ou incontestável, ainda assim embasam os pensamentos de novos doutrinadores espíritas. Podemos afirmar que se constitui enquanto Escola dentro do Espiritismo brasileiro, produzindo uma representação específica do que seja a sexualidade humana, a homossexualidade e o homossexual (PEREIRA, 2020). Não queremos afirmar que Divaldo seja unanimidade, mas a sua fala tem um peso e alcance que outros médiuns atuais não possuem, por isso a sua relevância ${ }^{3}$.

Justificando a escolha por Divaldo Pereira Franco, a partir da compreensão de que o processo de institucionalização e consolidação doutrinaria espírita brasileira se fortalece a partir das figuras de Chico Xavier (STOLL, 2004), e Divaldo, suas psicografias e reflexôes ajudaram na constituição e seleção da base doutrinária espirita no Brasil ${ }^{4}$ (STOLL, 2003). Podemos dizer que os discursos desses dois médiuns e intelectuais espíritas (ARRIBAS, 2017), se tornaram o leme da Doutrina no Brasil com a anuência da Federação Espírita Brasileira- FEB.

Constatamos que a FEB seleciona e divulga doutrinadores e temas, afastando dos holofotes os debates polêmicos (PEREIRA, 2020), consolidando os intelectuais e médiuns que corroboram com a sua perspectiva. O autor Pedro Paulo Amorim (2011, 2012), reforça essa compreensão ao realizar um recorte histórico mostrando que temas que desagradam a Federação Espírita Brasileira-FEB, tende a serem lançados ao ostracismo, ao esquecimento.

A FEB fala e faz falar, cala e faz calar. O silêncio fala, parece clichê, mas como nos ensina Eni Orlandi (2011, p. 68), "o silêncio não se caracteriza por ausência de palavras, ele é o que se estabelece entre as palavras”. Fazer calar não é apenas silenciar o outro, mas também fazê-lo sustentar outro discurso. Assim, a FEB ao negar-se discutir determinados assuntos, constitui um novo discurso. Será justamente por meio do discurso que não é verbalizado, aquele que só podemos ver e ouvir no silêncio, que se apresenta o discurso sobre a homossexualidade na doutrina espírita, bem como a representação se constitui nesses espaços interdiscursivos.

A estratégia de seleção e controle de conteúdo se instala. O controle se torna mais sutil, sendo delicada e racionalizada, em se tratando das sexualidades, aqui analisamos a homossexualidade masculina. Nomeamos esse controle exercido pela FEB e por seus doutrinadores como homeopática, lembrando a metodologia empregada pela homeopatia, dissolvendo o tema (sexualidade, sexo e homossexualidade) entre assuntos mais brandos, menos polêmicos e corriqueiros na doutrina.

Tendo essa compreensão, prosseguimos analisando as falas e posiçôes a respeito da homossexualidade, do homem que, hoje, personifica o espiritismo no Brasil, Divaldo Franco (PEREIRA, 2020), bem como dos adeptos a sua corrente de pensamento, que acreditamos ter constituído uma escola ou uma corrente dentro da doutrina espírita brasileira.

3 Em 2019, Divaldo ganhou uma cinebiografia intitulada: Divaldo- O mensageiro da paz. Além de Divaldo, somente Chico Xavier, 2010, e Bezerra de Menezes, 2008. Até mesmo o próprio Kardec não teve sua vida registrada em vídeo, apenas em 2019 foi lançado um filme que relata o processo de codificação e surgimento da doutrina espírita na França, onde Kardec é o protagonista no enredo.

$4 \quad$ A análise pode ser lida na Tese intitulada "Transar pode, mas você não deveria" A representação da homossexualidade no espiritismo brasileiro. Auto: Francisco Jomário Pereira. Universidade Federal da Paraíba. Programa de Pós Graduação em Sociologia. João Pessoa. 2020. 


\section{A HOMOSSEXUALIDADE E O DISPOSITIVO DO SABER-PODER-PRAZER}

Como forma de construir ou fazer ser vista a representação cunhada por Divaldo Franco sobre a homossexualidade, apontaremos citações extraídas da obra literária Sexo e Obsessão (2002), uma obra psicografada por Divaldo Franco e ditada pelo espírito Manoel Filomeno de Miranda, que versa sobre a obsessão. Para além do livro Sexo e obsessão, na busca da compreensão do processo de silenciamento sobre a homossexualidade, analisamos os livros, Divaldo Franco Responde, vol. 2. de 2013, e Sexo e Consciência de 2016.

A obra Divaldo Responde é fruto de uma entrevista concedida pelo médium, posteriormente publicado em formato de livro. Sexo e Consciência é uma obra que se origina das reflexôes a partir dos textos e obras já publicadas pelo médium, e sua guia espiritual Joanna de Angelis. Por fim, um discurso proferido em ocasião do 34º Congresso Espírita de Goiás de 2018.

Iniciando por uma análise de conteúdo, verificamos que em 187 páginas da obra Sexo e Obsessão, encontraremos apenas uma citação ao termo homossexual. Dessa forma nos ativemos as expressóes e descriçôes que versam sobre a homossexualidade, que estão contidas no contexto que trata dessa orientação sexual, pois, a estratégia é diluir o assunto sexualidade, não expondo termos que possam estimular a sexualização dos seus leitores.

$\mathrm{Na}$ busca da compreensão do processo de silenciamento sobre a homossexualidade, observamos nos livros Divaldo Franco Responde, vol. 2. 2013. Sexo e Consciência, 2016, a estratégia da homeopatia, é discutido o tema homossexualidade, mas ele é inserido e diluído entre outros temas, não existe uma publicação específica de Divaldo Franco sobre a homossexualidade.

Divaldo concebe a homossexualidade como uma condição, mas não na mesma esfera que a condição masculina ou feminina. Não seria uma opção nascer gay, mas um fato que ocorre devido a fatores anteriores ao nascimento, podendo ou não, posteriormente ao nascimento, desencadear as experiências da homossexualidade. Os fatos anteriores ao nascimento derivam de uma programação ou reencarnação não tão bem-sucedida, os posteriores estáo atrelados as condiçóes morais do indivíduo e da sociedade, especialmente em sua educação.

Na obra literária Sexo e Obsessão (2011), teremos a narrativa da vida e problemas enfrentados por Mauro, um jovem sacerdote católico, que se torna pedófilo, será sobre a batalha pessoal, moral e espiritual travada por esse sujeito que o livro versa. Divaldo inclui nessa narrativa o debate sobre as perversóes sexuais, incluindo a homossexualidade.

A narrativa começa com a descrição do universo, e da colônia espiritual onde ele, Manoel Filomeno de Miranda, espírito que dita e narra a história, se estabeleceu pós desencarne. Nos é narrado que as ações de Mauro no presente, tem relações estritas com seu passado, débitos pretéritos que ainda não foram sanados.

Observamos na narrativa que existem dois lugares antagônicos, teremos o lado da luz, tanto a colônia espiritual de onde partem os benfeitores, como o Centro espírita que se conecta a essa colônia, como se fosse uma subsidiária no plano físico na Terra, e um lugar de trevas, conhecida como cidade perversa, que é administrada pelo Marquês de Sade, figura icônica e histórica.

Face aos processos evolutivos, muitos espíritos transitam na condição homossexual, o que lhes permite comportamentos viciosos, estando previsto para o futuro, um número tão expressivo que chamará a atenção dos psicólogos, sociólogos, pedagogos que deverão investir melhores e mais amplos estudos em torno dos hábitos humanos e da sua conduta sexual. (FRANCO. 2011, p. 115) 
Observamos que a obra Sexo e Obsessão guarda semelhanças com narrativas de outras denominaçóes religiosas, especialmente as pentecostais e neopentecostais, no tocante aos percursos realizados para a libertação de homens da homossexualidade e outras obsessôes. Marcelo Natividade (2008), nos apresenta a representação que os evangélicos pentecostais constroem a respeito da homossexualidade, e de como essa representação é associada a figura do demônio, sensualidade, sexualidade, ao prazer, bem como a entidades e divindades da cosmologia do Candomblé e Umbanda.

Neuza Itioka, uma escritora evangélica reconhecida no meio, ministrou a
"restauraçấo sexual" e enfatizou que a sexualidade era uma das esferas da vida
sujeita a "ataques malignos". Os brasileiros, em especial, tinham sérias lutas
espirituais nessa área. No Carnaval, principalmente, as pessoas eram tomadas
por "espíritos de prostituição" e eram levadas à "idolatria do sexo". Nesta festa
pagá dominada por pomba-giras e por outros exus, o demônio reinava, usava
os corpos, espalhava doenças, aumentava a violência. O crente era exortado a se
manter vigilante, em oração. (NATIVIDADE, 2008, p. 99)

Constatamos em Sexo e Obsessáo passagens que se relacionam estritamente com o que Natividade apresenta. Divaldo Franco narra ter realizado viagem astral a um lugar conhecido como cidade pervertida, lugar de horror, perversão e animalização. Segundo a crença espírita é comum a prática de viagens astrais entre alguns médiuns e aparentemente doutrinadores de outras religióes, observa-se em especial essa prática na cosmologia religiosa quando ocorre um processo de luta para libertar alguém de alguma entidade maligna.

Divaldo afirma ter vislumbrado em projeção astral na cidade pervertida, espíritos "vitimados por graves alteraçóes e mutilaçóes no perispírito" desenfreados exaltando o sexo e das suas mais sórdidas expressóes. [...] "carregando-se uns aos outros, acompanhando freneticamente um desfile de carros alegóricos, que faziam recordar os carnavais da Terra” (p. 24) (grifos nossos).

O médium Divaldo ressalta e faz referências com o que se passa no plano terrestre. Afirma que os "espetáculos de grosseira manifestação da libido, nos quais se mesclavam apresentaçóes de conúbios sexuais entre animais e seres humanos deformados sob o aplauso descontrolado da massa desnorteada" (p. 24). Seria bem parecido com o que ocorre em nossos carnavais. Como forma de contrapor a "indecência", se criou carnavais religiosos, a exemplo temos o Movimento de Integraçáo do Espírita Paraibano- MIEP que em 2020 realizou seu 470 encontro. Assim, observamos a existência de um padrão, onde, os pentecostais, neopentecostais e espíritas concordam parcialmente, sobre o carnaval brasileiro.

Em ambos os casos, espírita e (neo) pentecostal, a influência desses espíritos malignos poderiam ajudar no desenvolvimento e vivência da homossexualidade. Para os pentecostais a homossexualidade ou o demônio da homossexualidade se instala por meio de brechas que o pecado abre, já no espiritismo por meio de afinidade mental, quanto mais a mente do sujeito for inundada de estímulos sexuais, mais próximo de espíritos atormentados estaria o sujeito, ficando suscetível aos controles e comandos do espirito malfazejo.

A mente é a construtora da vida, é a partir dela que "provem a energia com a qual são condensados os anseios e as necessidades de todas as criaturas" (FRANCO, p. 27), por isso a necessidade de mantê-la limpa e longe de estímulos sexuais, a partir dessa concepção, os livros não trazem explicitamente narrativas que possam estimular ao sexo, essa constatação pode ser feita a partir de falas de Divaldo Franco. 
Sexo e Obsessão guarda semelhanças com um tipo de produção editorial especifica das denominaçôes (neo) pentecostais, os manuais de cura e libertação. No espiritismo encontramos manuais de boas maneiras, manuais com recomendaçóes, nada muito explícito ou no imperativo, nada que denote rituais para a libertação da alma, mas para o controle e educação, apresentam conselhos e procedimentos para a sublimação da sexualidade e a abstinência sexual, em especial quando trata-se da homossexualidade. Será na adoção de um tom ameno, que foge ao imperativo, que o espiritismo ganha ares de religião acolhedora.

Na obra Divaldo Responde, volume 2 (2013), Divaldo busca responder questionamentos sobre conflitos conjugais, pais e filhos, adoção, sexualidade, homossexualidade, felicidade, desigualdades sociais, aborto, entre outros temas. De imediato, observamos que não existe uma pergunta ou uma resposta sobre o que seria a homossexualidade, existe um capítulo que versa sobre causas e efeitos da existência da homossexualidade.

O primeiro tópico é, causas da homossexualidade, no questionamento levantado encontramos os termos genética, convivência familiar, doença, ou influência do meio social, por fim, a questáo: O que faz uma pessoa ter comportamentos homossexual? Divaldo, entáo, inicia a resposta citando a Organização Mundial da Saúde (OMS) e o processo de retirada da homossexualidade do Código Internacional de Doenças- CID, evento esse que ocorreu, segundo Divaldo, em decorrência dos estudos da psicologia comportamental que mostraram que a homossexualidade não era um problema psiquiátrico, mas sim uma questão de escolha ou melhor dizendo, opção, mas deixa claro e reforça que a homossexualidade é uma "tendência que tem origem na vida espiritual" (2013, p. 119).

Observa-se que o médium recorre ao discurso de autoridade para justificar a sua resposta, para se resguardar, ele apresenta a questão de número 200 do Livro dos Espíritos, e segue falando das polaridades. Divaldo (2013) faz um adendo para explicar o uso do termo opçáo pessoal, deixando claro que essa opção é somente em se tratando do comportamento sexual, e segue afirmando que amar alguém do mesmo sexo é perfeitamente normal.

Nos chama a atenção a lógica de separação efetuada por Divaldo Franco, ele separa amor/ afeição do sexo, amar é possível e até aceito, mas a prática sexual entre duas pessoas do mesmo sexo é reprochável, essa deve ser sublimada. "Mas não consideramos que se trate de uma patologia, nem que signifique um distúrbio de comportamento, ou uma conduta de natureza reprovável” (2013, p. 120).

Ainda no livro Divaldo Responde. Vol. 2, Franco (2013), é solicitado a explicar o que seria ou como seria o comportamento que choca a sociedade: "o que pensar daqueles homossexuais que têm um comportamento de deboche, escandaloso, e que, as vezes chocam a sociedade" (p. 122). $\mathrm{O}$ inquirido responde de forma fugidia, afirma que, independentemente de ser homossexual ou heterossexual, os escândalos morais chocam a sociedade, o organismo social, e que essas agressóes denotam transtornos de conduta merecendo terapia na busca de um ajuste à sociedade.

Na obra Sexo e Consciência (2016) no capítulo sete, intitulado Homossexualidade, ele torna a tratar desse tema de forma mais específica e contundente.

É importante que o indivíduo que opta por se relacionar com pessoas do mesmo sexo evite posturas de confronto com aqueles que o não compreende ou não aceitem. Será inútil uma explosão de amargura ou atitude autodestrutiva, na ânsia de ferir e dar uma resposta incisiva à sociedade que o oprime. São posturas absolutamente injustificáveis, haja vista que nenhum desafio existencial será revolucionado por intermédio de exibiçâo agressiva de nossos dramas íntimos. O respeito ao grupo social é fator preponderante. Ninguém deve impor sua 
orientaçáa sexual como se ela fosse um comportamento que todos devem reproduzir. (FRANCO, 2016, p. 206)

Observamos que Divaldo parte da noção de uma heteronormatividade natural, dada, estruturalmente aceita e incontestável, esquece que a sexualidade é um constructo social regulado por normas, valores cristãos ou não, cultura, política, uma economia da sexualidade e assim passível de transformaçôes. Destarte, Daniel Borrillo (2015), nos explica de onde provém a lógica reproduzida por Divaldo Franco.

A lógica reproduzida por Divaldo, provém da existência de uma "ordem sexual a partir da qual são organizadas as relaçóes sociais entre sexos e as sexualidades. A origem da justificativa social dos papéis atribuídos ao homem e à mulher encontra-se na naturalização da diferença entre dois sexos" (p. 30), ou seja, apenas entre dois sexos e uma sexualidade possível, a hétero. Tudo que possa existir fora dessa ordem tida como natural, será vista como uma afronta ao corpo social que o médium defende.

Divaldo se insere entre os escritores que compartilham da ideia do heterossexismo, deste modo, seu discurso é norteado por uma heterossexualidade compulsória, ou seja, uma imposição como modelo das relaçóes amorosas e sexuais (Miskolci, 2012). Mas podemos observamos contradiçóes na fala de Divaldo, e questionamos, se ninguém pode impor sua sexualidade como um comportamento que todos devam reproduzir, o que dizer da heterossexualidade enquanto norma instituída, reproduzidas e incontestada por Divaldo?

Divaldo aconselha os homossexuais a aceitarem sua condição de forma recatada, resguardar seus sofrimentos e preconceitos que possam vir a sofrer, ainda justifica qualquer atitude de agressão afirmando que agressores por estarem "na gaveta" ou "enrustidos", refletem nos outros a sua ira, porque gostariam também de ter a mesma coragem de assumir a sua manifestação desta ou daquela natureza.

Ao hostilizarem o outro ser, estão projetando a imagem negativa, numa catarse inconsciente, para liberta-se do conflito". (FRANCO, 2013, p. 126). Essa lógica seria produto da heteronormatividade, da ordem sexual estabelecida, fundada em um modelo heterossexual, que o próprio Divaldo defende, baseado na reprodução e com famílias tradicionais, "é um regime de visibilidade, ou seja, um modelo social regulador das forma como as pessoas se relacionam" (MISKOLCI, 2012, págs, 41-42).

Para além de Miskolci, Foucault (2001), nos leva a refletirmos sobre o processo de constituição da heteronormatividade como uma ideologia de gênero, essa, exclusivamente aceita como norma. Pode chocar o uso do termo ideologia de gênero dentro do contexto em que apresentamos, mas devemos nos apropriar do debate político atual para buscar refletir e explicar esse fenômeno que tem influenciado os debates atuais sobre a sexualidade, e que recentemente foi usado por Divaldo em um de seus discursos.

Chamamos a atenção para o conceito de Ideologia de Gênero, surgido publicamente em 2016, na tentativa de mostrar que a única ideologia hegemônica é a que Divaldo defende em seus livros e discursos. Não é por acaso que ele afirma que todo sujeito que procura demonstrar publicamente o seu conflito, no caso ser homossexual, estaria agredindo a sociedade, sendo indicado como como remédio a terapia, pois, somente por meio da terapia o sujeito homossexual poderá analisar suas questóes íntimas. Ainda segundo Divaldo, devemos considerar que cada cidadão deve respeitar as leis e o contexto cultural que têm vigência nos grupos sociais que ele integra. 
O médium Divaldo (2016) observa como agressão ao corpo social o fato de homossexuais imporem sua presença física de modo chamativo, sendo considerado uma afronta. Podemos questionar se essa agressão ao corpo social poderia ocorrer mediante a busca por direitos civis, mesmo tendo o médium afirmado que, todos têm direitos iguais diante de uma sociedade estabelecida.

Devemos salientar que, respeitar não implicar em não contestar, e que mudanças e direitos sociais foram conquistados mediantes revoltas, lutas, e contestação do status quo estabelecido. $\mathrm{O}$ próprio espiritismo surge enquanto contestaçáo, surge como ideia revolucionária, acaba sendo fruto do período de grandes mudanças na França e na Europa no século XIX.

Mudando o foco da análise para um discurso verbalizado, Divaldo Franco continua reforçando verbalmente as representaçóes expostas acima.

Em um dos seus mais recentes e controversos discursos, critica a "ideologia de gênero" durante o 34 Congresso Espírita do Estado de Goiás realizado em 2018, que reproduziremos quase que na íntegra, pois cremos ser de extrema importância para analisar o viés ideológico que permeia o espiritismo pensado por Divaldo. O questionamento feito foi o seguinte: o que você pode dizer sobre ideologia de gênero?

Eu diria em frase muito breve, que é um momento de alucinação psicológica da sociedade. (risos e palmas). Mesmo porque, nós vamos olhar a criança graças a sua anatomia, como sendo o tipo ideal, e a criança nesse período não tem discernimento sobre o sexo, a tese é profundamente comunista, e ela foi lançada por Marx, sobre outras condições, que a melhor maneira de submeter um povo não era escravizálo economicamente, era escravizá-lo moralmente, como nós vemos através de vários recursos que tem sido aplicados no Brasil nos últimos nove anos, dez.... [...] Todas essas manifestaçóes que estamos vindo, graças a república de Curitiba, cujo presidente é o Dr. Mouro, e deve ser... (palmas) O desnudar da hipocrisia e da criminalidade, [...] e o nosso venerando juiz não provocou o escândalo, atendeu a uma denúncia, muito singela, e, no entanto, levantou o véu que ocultava crimes hediondos, [...]. Mas, determinados comportamentos, de alguns do passado muito próximo, estabeleceram o marxismo disfarçado e a corrupção sob qualquer aspecto, como um princípio ético. A teoria de gênero é para criar na criança, no futuro cidadão, a ausência de qualquer princípio moral. Uma criança não sabe discernir, somente tem curiosidade, no mesmo banheiro um menino e uma menina irão olhar-se biologicamente sorrir e perguntar de que se tratava aquele aparelho genésico, que é desconhecido. Então nós defendemos repudiar de imediato e apelar para aqueles em quem nós votamos, somos responsáveis, e gritar para eles que somos contra, totalmente contra essa imoralidade ímpar. (palmas) [...] É necessário que nós tenhamos voz. [...] Muitas aberraçôes nos silenciamos, afinal disfarçadamente vivemos numa república democrática, [...] $\mathrm{O}$ aborto provocado, esse crime hediondo, que está sendo tentado tornar-se legal, por mais que seja legal, nunca será moral. Náo somos contra quem aborta por essa ou aquela razão, falamos em tese matar é crime, seja qual for a aparente justificativa, e agora com a tese de gênero, estamos indiferentes, e de um momento para outro pela madrugada os nossos dignos representantes adotam. Falávamos ontem a respeito de cartilhas do Ministério da Educação depravadas, para corromper as crianças, e que as escolas estão devolvendo ao Ministério. [...] os pais devem vigiar os livros dos seus filhos, e naturalmente recusarem, nós temos o direito de recusar, nós temos o dever de recusar. [...] Então precisamos ser mais audaciosos, espíritas, definidos, termos opinião. A doutrina nos ensina, e para os jovens, eu direi que 
há uma ética, liberdade, o sexo é livre. Livre sim. Mas ele não tem a liberdade de indignificar a sociedade, poderemos sim exercer o sexo, é uma função do corpo, e também da alma, mas com respeito e com a presença do amor. Portanto, a teoria de gênero, jamé. (palmas). (Divaldo Pereira Franco, fevereiro de 2018, $34^{\circ}$ Congresso Espírita de Goiás) ${ }^{5}$

O discurso proferido por Divaldo reforça o que está escrito, mesmo de forma confusa, creio ser uma estratégia, fazendo uso do senso comum, incluindo o marxismo em um debate sobre sexualidade, comprando e reproduzindo um discurso propagado pela única ideologia de gênero existente e hegemônica, a heteronormativa, que tem cor e classe social.

A narrativa que Divaldo elabora cita a escola e suas práticas educativas, ou melhor, o que elas deveriam ser ou representar, dando o direito aos pais, mais uma vez, de vigiar os seus filhos. Podemos observar a ação do dispositivo do saber-poder-prazer agindo, seja mediante a fala do médium, ou das atitudes que os pais deveriam tomar. A lógica empregada e observada durante todo o discurso de Divaldo, o seu conhecimento, o seu saber, produzem poder que permear e orientar a construção que se faz da política, do sexo, do gênero, da homossexualidade, e por fim, do prazer.

Quando Divaldo delega à família o papel de ensino e vigilância à criança, reforça com seu discurso toda uma tradição religiosa cristá que foi responsável por instituir e aprimorar um dispositivo que atua no campo de vigilância e disciplina, especialmente sobre os corpos ainda em formação, hoje, isso ocorre de forma sutil, mas já foi bastante explicita.

A tecnologia surgida no século XVIII tem a capacidade de tornar dóceis os corpos e mentes, não apenas por meio da vigilância e disciplina, para além, ela implica mudanças de comportamento, mudança nos hábitos sexuais, e segundo o próprio Foucault (2015), "um tipo de formação que, em um determinado momento histórico, teve como função principal responder a uma urgência. $\mathrm{O}$ dispositivo tem, portanto, uma função estratégica dominante" (2015, p. 365).

A estratégia é produzir mudanças profundas onde possa se instituir novos termos e conceitos que provém de campos de conhecimentos diversos, assim se deu, por exemplo, o surgimento do termo sexualidade, "um conjunto de regras e de normas, em parte tradicionais e em parte novas, e que se apoiam em instituiçóes religiosas, judiciárias e médicas; como também as mudanças no modo pelo qual os indivíduos são levados a dar sentido e valor à sua conduta, seus deveres, prazeres, sentimentos, sensaçóes e sonhos" (FOUCAULT, 2017, p. 08).

Observa-se que nos dias atuais se modificou, ganhando novas versóes quanto aos termos, chegando até a nova ideia de Ideologia de Gênero, não podemos chamar de conceito, por enquanto, já que o mesmo deverá ser construído nessa relação de dominação, e por conseguinte, apropriada não apenas pelo discurso de senso comum, mas academicamente, para ser combatido e repensado, são essas as relaçóes instituídas pelo dispositivo da sexualidade.

Conforme pode se observar, o discurso produzido pelo espiritismo de Divaldo Franco tem a característica de ser sutil, algo que não ocorreu no discurso proferido no congresso espírita e que fizemos uso, são esses momentos em que podemos observar que a dominação não ocorre sem resistência, e que os dispositivos podem ser falhos.

5 A fala de Divaldo gerou reação por parte da comunidade espírita, um grupo intitulado de Espíritas Progressistas lançaram uma carta contestando a fala polêmica, bem como abrindo espaço para um abaixo-assinado ratificado por diversos espíritas, intelectuais, diretores de Centros e médiuns. A ação demonstrou que existe resistência a postura adotada pelo médium nos últimos anos. Link para acessar a carta. < https://www.comkardec.net/nota-de-resposta-divaldo-haroldo/> Acessado em 17 de junho de 2020. 
O discurso de Divaldo sobre a homossexualidade ou sexo tende a ser sutil em seus livros, especialmente. Em suas palestras ele tende a fazer referência as obras publicadas, talvez por isso ele tenha perdido o tom ao tratar publicamente da ideologia de gênero, ele não escreveu nada, em específico, sobre o assunto, isto posto, ele consegue reinterpretar e criar uma concepção racional e aceitável sobre a sexualidade e sua vivência.

Dessa forma, observamos que o espiritismo brasileiro e sua narrativa sobre a homossexualidade são produtos do dispositivo poder-saber-prazer. O discurso está diretamente relacionado a momentos históricos de transformaçôes, começando nos séculos XIX e XX. Assim nos ensina Foucault quando nos explica:

Dispositivo se constitui à medida que engloba um duplo processo: processo de sobredeterminação funcional, pois cada efeito, positivo ou negativo, desejado ou não, estabelece uma relação de ressonância ou de contradição com os outros, e exige uma rearticulação, um reajustamento dos elementos heterogêneo que surgem dispersamente; por outro lado, processo de perpétuo preenchimento estratégico. (FOUCAULT, 2015, p. 365)

O espiritismo pode ser pensado enquanto efeito, não podendo afirmar se positivo ou negativo, desejado ou não, mas estabelece uma relação contraditória com as demais religiōes cristãs, não é à toa que foi combatida pelo catolicismo durante o século XIX e XX. Observamos a junção de elementos heterogêneos como a filosofia, ciência positivista, psicanálise, psicologia e a própria religião, que são combinados e recombinados, assim nasceu o espiritismo, e ao chegar no Brasil ganhou nova roupagem, adicionado a ele o aspecto da caridade e do personalismo.

\section{SER OU NÃO SER E A NECESSIDADE DE SUBLIMAR}

Partido da possibilidade de dúvidas quanto a ser ou não homossexual, Divaldo responde que o ideal "seria que cada um de nós mantivéssemos o equilíbrio entre a polaridade psicológica e a organização física" (2013, p. 128). Observamos que esse "equilíbrio" é pensado a partir da ideia de sujeito normal, que é conceituado pela doutrina jurídica, pela doutrina médica e religiosa que se constituem enquanto tecnologias de poder, que surgem como forma de evitar convulsóes que o corpo pode ter devido a uma sexualidade não sã, cristá, e juridicamente legal (FOUCAULT, 2001).

O homossexual aparece como o indivíduo a ser corrigido, pois, ao vivenciar a homossexualidade, prova que as técnicas de controle e vigilância fracassaram (idem, 2001). Tendo as técnicas de controle fracassadas, restam as intervençóes que garantam ou possibilitem uma reeducação do seu modo de ser e agir. É com o intuito de reeducar aquele que a família não conseguiu educar, que surge a técnica de sublimação pensada pelo espiritismo. A sublimação enquanto técnica não é exclusiva do espiritismo, mas diverge do catolicismo quanto a restrição ao ato sexual em si.

Podemos observar na obra O Livro dos Espíritos, que não existe a obrigatoriedade do celibato, diferente do catolicismo. A sublimação pensada pelo espiritismo pode passar pelo celibato, mas não é uma regra, pois, se for extremamente necessário para evitar um "mal maior", pode-se manter relaçóes sexuais, desde que dentro de um padrão socialmente aceito como normal. Divaldo Franco consegue se desresponsabilizar pelo que afirma, quando, inicialmente nos diz que "desde 
que estejamos reencarnados na masculinidade, cabe-nos o dever e o direito de manter a dignidade masculina, o que não quer dizer que aquele que opta pela homossexualidade seja indigno" (2013, p. 128). (Grifos nossos)

Ao frisar o termo, manter a dignidade, questionamos, o que podemos entender por ele? É indigno ser homossexual? Cremos que Divaldo Franco se contradiz, pois, afirma que a questão em si não é ser homossexual. Na sua concepção seria devidamente normal ser homossexual, o problema reside no ato, na prática sexual homossexual, que diverge da norma heterossexual estabelecida, como já posto.

Observamos ainda a lógica machista implícita, já que aquilo que lembra o feminino é problemático. Não conseguimos compreender o que seria manter essa dignidade masculina, a não ser compreendendo como algo que não se deva relaciona o homens a postura e identidade vinculada ao feminino, muitas das vezes sendo chamados de afeminados.

Seria mais tolerável a existência do homossexual mais masculino em detrimento daquele que possui trejeitos femininos? Supostamente o sujeito afeminado abriu mão da masculinidade, algo totalmente imperdoável em uma sociedade machista e sexista que concebe o feminino como algo frágil e inferior.

Para além do sexismo, observamos o fenômeno da homofobia, algo que Daniel Borrillo (2015) pode nos esclarecer melhor, pois vem a ser "uma manifestação arbitrária que consiste em designar o outro como contrário, inferior ou anormal; por sua diferença irredutível, ele é posicionado a distância, fora do universo comum dos humanos" (p. 13). Mesmo afirmando que o sujeito que opta pela homossexualidade seja digno, Divaldo Franco consegue de modo implícito reforça a lógica sexista que beira a homofobia.

Não afirmamos que a Doutrina Espírita ou os espaços públicos dedicados a Doutrina siga a lógica homofóbica ou discriminatória, não temos condições para tal afirmação, mas percebemos em seu discurso posiçóes que reproduzem, muitas das vezes o senso comum, em se tratando da homossexualidade.

Seguindo com a análise, observamos que o médium tergiversai ao ser solicitado que expresse palavras para aqueles que assumiram a condição homossexual, então, afirma que "quando tomamos uma decisão, devemos arcar com as consequências que decorrem da nossa atitude. Se um indivíduo optar por qualquer comportamento [...] ou conduta moral, naturalmente isso tem um preço. E esse preço deve ser pago, no bom sentido da palavra” (2013, págs, 125-126), qual o bom sentido que podemos empregar?

Para o doutrinador, seria a aceitação de si mesmo, da autoestima, sem valorizar demasiadamente a opinião alheia. Na nossa interpretação bastaria que o homossexual se amasse, se aceitasse e tudo ficaria bem, independente do que os outros digam. Um preço pequeno a se pagar por ser homossexual, na verdade não entendo como isso pode ser visto como preço, então, Divaldo complementa:

Porque muitas pessoas são agressivas quando têm conflitos semelhantes e não conseguem assumir a sua realidade interior. Como se diz em linguagem popular "estấo na gaveta", "estáo enrustidos" e refletem nos outros a sua ira, porque gostariam também de ter a mesma coragem de assumir a sua manifestação desta ou daquela natureza. Ao hostilizarem o outro ser, estão projetando a imagem negativa, numa catarse inconsciente, para libertar-se do conflito. (FRANCO, 2013, p. 126) 
Observa-se que ao conseguir ficar bem consigo e com a sua sexualidade, se evitaria agressóes aos demais que náo compartilham da mesma orientação sexual. Mas devemos lembrar que nem todos que praticam o crime da homofobia "estão na gaveta" como disse Divaldo, esses sujeitos estão orientados por uma lógica naturalizada e que podemos observar sendo reforçada durante os textos analisados, inicialmente ele pede que o ofendido náo responda as agressôes, que apenas aceite e busque entender, e por fim justifica as açôes daqueles que também são vítimas do sistema instituído.

Divaldo ainda abre para a possibilidade para uma readequação sexual do indivíduo homossexual, aconselhando procurar um terapeuta para que seja auxiliado.

Se ele acredita possuir uma estrutura psicológica para exercer a sua sexualidade dentro da orientaçấo convencional, que contempla a função biológica da reproduçáo seria recomendável o apoio de um terapeuta que o auxilie a tentar um trabalho de autoconhecimento. Com o recurso da terapia ele poderá autodescobrirse, verificando se consegue ultrapassar barreiras inerentes às suas dificuldades afetivas. Mas isso terá que ser feito de uma forma muito criteriosa, para que não se configure uma situação forçada e artificial que só trará consequências negativas, contribuindo para a infelicidade do indivíduo. (FRANCO, 2016, p. 207)

Não intentamos colocar a ideia proferida por Divaldo Franco em pé de igualdade com a lógica da cura gay, tratamentos oferecidos por determinadas denominaçôes religiosas que buscam a conversão do homossexual em heterossexual. Apenas nos questionamos por qual motivo Divaldo Franco insiste na adoção de uma sexualidade convencional, como ele afirma, se o mesmo salienta e explica da existência de quatro tipos de orientaçôes sexuais (2016, p. 191), a heterossexual, assexual, homo e a bissexualidade.

Detectamos, a partir das análises, existe o reforço, um estímulo para se alcançar e exercer a heterossexualidade, ou a sexualidade convencional na concepção do médium, ou a sublimação de qualquer prática sexual, se for incorrer em erros ou abusos. Por mais que Divaldo se esforce para transparecer que o livre arbítrio deva ser exercido, e que o que ele escreve ou fala, devem ser vistos apenas como meros conselhos, observamos que o oferecimento desses conselhos, como o citado acima, denotam uma outra percepção, a de que ele deve ser ouvido e seguido, pois é exemplo de como se deve proceder a sublimação sexual, pois, para conseguir sublimar de forma correta, o indivíduo deve gozar de resistência moral.

Assim, por ter sublimado sua sexualidade, ele gozaria de uma moralidade em que pudesse se colocar como superior e como exemplo a ser seguido, característica do personalismo. "A sublimação depende das resistências morais de cada um. Eu, por exemplo, sou solteiro e não experimento nenhum conflito, pois disciplinei a mente para alcançar este objetivo. Desde cedo criei hábitos mentais que respondem pela minha tranquilidade emocional e afetiva. Preencho os vazios existenciais com outras motivaçôes" (FRANCO, 2016, p. 215).

Divaldo Franco goza de uma posição privilegiada e de respeito, faz uso do discurso de autoridade, então, tem um impacto maior entre seus leitores e seguidores, esse discurso interfere na percepção que sujeitos homossexuais tem da vivência da sua sexualidade (PEREIRA, 2020). 


\section{DIVALDO FEZ ESCOLA}

Observamos que a forma como Divaldo fala, escreve e se apresenta impacta e interfere na forma como recebemos, lemos e interiorizamos o seu discurso. O uso de termos técnicos, mais elaborados, até mesmo complicados, interferem na nossa compreensão. Podemos dizer que Divaldo criou uma escola, essa escola tem alunos, e alunos escrevem, pensam, e reescrevem os ensinamentos dos mestres. Crendo que isso ocorra, Alírio de Cerqueira Filho (2014), como bom aluno, enveredou pelas questôes da sexualidade, sexo e homossexualidade, buscando respostas e dando explicaçóes baseadas em respostas obtidas por meio de questionamentos aos espíritos, mesma metodologia adotada por Allan Kardec.

Podemos observar o emprego da mesma metodologia adotada nos primeiros tempos do espiritismo, em seu livro Sexualidade e Saúde Espiritual: Reflexóes sobre sexo, sexualidade e sexualismo (2014), onde discorre de forma desenvolta, sem muitos arrodeio sobre temas polêmicos e de difícil abertura no mundo espírita. Em pouco mais de 250 páginas e seis capítulos, ele vai de perguntas e respostas a dissertaçóes atinentes à sexualidade e à saúde espiritual.

O segundo capítulo nos chama a atenção, intitulado de: questôes sobre o sexo, sexualidade e sexualismo, está dividido em sete partes, sendo elas: sexo e saúde espiritual; sexo e erotismo; homossexualidade e homossexualismo; parafilias; disfunções sexuais; sexo e obsessão; sexo, saúde e espiritualidade, totalizando 66 perguntas realizadas aos espíritos e prontamente respondidas, sobre o tema do sexo e suas derivaçóes.

Nos chama a atenção o ponto 2.3 do referido capítulo, onde encontramos nove perguntas em torno da Homossexualidade e Homossexualismo. As perguntas permeiam a existência, como evitar, como conviver e como superar a homossexualidade e o homossexualismo. As ideias apresentadas não se distanciam da apresentada por Divaldo Pereira Franco.

As respostas são oferecidas pelos Mentores espirituais, para além, se resguardam na doutrina espírita por meio dos livros de Kardec, mas recorrem a Divaldo Franco e Chico Xavier, demonstrando assim, que, não nos enganamos quando afirmamos que ambos, Chico Xavier e Divaldo Franco, personificam e ditam preceitos doutrinários que são reproduzidos e ressignificados nos centros e casas espíritas do Brasil.

Ao analisarmos a obra de Alírio de Cerqueira Filho, nos chama a atenção o uso do termo homossexualismo, o autor utiliza o termo para distinguir de homossexualidade. O homossexualismo seria a prática, algo totalmente contornável, em sua perspectiva, a homossexualidade seria uma condição que se dá em decorrência de vícios trazidos de outras vidas. $\mathrm{O}$ vício seria:

Por exemplo, um homem que se vicia de maneira heterossexual, tendo conúbio com muitas mulheres, sem respeitá-las, e isso passa a ser uma constante em sua vida, agravando o vício psíquico reencarnação após reencarnação, quando o Espírito reencarna na outra polaridade para aprender a valorizar os patrimônios femininos, o psiquismo está viciado, logo, a sua psicologia íntima não consegue pensar em termos de psicologia feminina no que se refere ao sexo, pensa em psicologia masculina porque não é a Lei jamais derrogada e o indivíduo no uso de seu livre- arbítrio precisa se responsabilizar por aquilo que escolheu. (CERQUEIRA FILHO, 2014, p. 55)

Com esse entendimento, podemos observar que o autor tentar resguardar a doutrina de qualquer indução ao erro, ou falta de explicação, pois, a homossexualidade ocorreria devido a um vício 
pré-existente e decorrente de outra vida. Alírio afirma que não existem falhas no processo reencarnatório, e que tudo que ocorre deve ser tomado por aprendizado, como um convite a educação. Cerqueira Filho (2014), ainda afirma que existe diferença entre ser homossexual e praticar o homossexualismo. Ser homossexual não é uma escolha, pode ocorrer, mas aparentemente não é a regra.

Cerqueira Filho adota Divaldo Franco como referência, afirma que o espírito busca a evolução psicológica em duas polaridades, feminina e masculina, somente quando conseguimos equilibrá-las, vivencia-las plenamente, é que o espirito terá conseguido progredir. Assim, a grande maioria dos problemas apresentados no campo da sexualidade, seria em decorrência da não adequação do corpo físico a polaridade psicológica programada pela reencarnação, essa falta de adequação, segundo Alírio, ocorre devido a vícios psicológicos trazido de outras vidas, pois, segundo o autor, não resta dúvida de que o processo reencarnatório é muito bem pensado, elaborado e executado, não existiria erros nos desígnios do Criador.

Exemplificando, "não é a reencarnação em uma polaridade ou outra que faz o indivíduo buscar o homossexualismo" (CERQUEIRA FILHO, 2014, p. 53). Alírio afirma que, "uma coisa é a homossexualidade, outra coisa é a prática do homossexualismo" (2014, p. 57). O autor insiste em distinguir os termos, e adota o sufismo, "ismo", que foi abolido do Código Internacional de Doenças- CID-10 (1992) (Classificação de transtornos mentais e de comportamento), acaba por reforçar negativamente a prática do ato sexual entre duas pessoas do mesmo sexo.

O doutrinador Alírio exorta o combate ao incentivo ao "homossexualismo". Reforçando à necessidade de se combater a propaganda dessa prática que gera vícios a partir da repetição dos mesmos erros reencarnação após reencarnação. Essa afirmação reforça estereótipos que colocam a prática sexual homossexual como problema, lembrando o período em que era considerada doença, transtorno mental e de comportamento. Observamos a mesma lógica reproduzida no e pelo senso comum, o problema não é ser homossexual, mas praticar o ato sexual.

Estudiosos do comportamento humano que estimulam seus pacientes à prática do homossexualismo não compreendem ainda a função do Espírito imortal na matéria. [...] a ideia de estimulá-lo a essa prática em nada corresponde com o movimento saudável, porquanto não é a prática homossexual que vai fazer com que ele se sinta pleno e realizado, tanto quanto não é a prática heterossexual que faz alguém feliz. O que faz o indivíduo feliz é a entrega afetiva, a prática afetiva em si mesmo, ao outro, e em relação à vida. (CERQUEIRA FILHO, 2014, p.57)

Para compreendermos a distinção entre homossexual e homossexualismo, que Alírio Cerqueira Filho nos impóem, é necessário observar que seu discurso se insere, ou faz parte de complexas relaçôes exercidas por uma organização social que considera a heterossexualidade monogâmica como ideal no plano afetivo e sexual (BORRILLO, 2015).

Sabemos que muitos homossexuais, na Terra, vivem de maneira digna, uns com os outros, respeitando-se, enquanto casal homoafetivo" (CERQUEIRA FILHO, 2014, p. 61). Resta ao homossexual duas escolhas, primeiro, sublimar, seria a mais acertada, segundo casar e manter uma relação estável homoafetiva, dentro dos padróes elegidos como saudáveis pela sociedade moderna que se baseia em códigos sexistas. 


\section{CONSIDERAÇÕES}

As concepçôes e ideias apresentadas por Divaldo Franco, e Alírio de Cerqueira Filho se inserem na tentativa de responder a uma demanda social que surge mediante a despatologização da homossexualidade, que seria política e moral. A demanda poder ser pensada a partir do questionamento, o que fazer com aqueles que vivenciam uma sexualidade fora da heteronorma? Sem agredir os seus corpos, ou restringir os seus direitos civis? Antes de 1992, ano de mudança no paradigma, era simples, terapia, medicalização, psiquiatria, afinal, era uma doença.

Mas o que fazer pós mudança? O próprio dispositivo da sexualidade responde, tendo em vista que ele se apropria e adequa o discurso ao seu interesse. Foucault (2015) nos informa sobre esse fenômeno ao afirmar que existe uma estratégia que perpassa pelo controle-estimulaçáo (2015, p. 236). Ou seja, deve-se eleger, designar quem pode falar sobre o tema e onde falar sobre. Assim, Divaldo Franco, Alírio e a FEB, por exemplo, são vistas como pessoas/entidades capacitadas para debaterem o tema sexualidade/homossexualidade no contexto espírita, o espaço reservado ao debate seria o centro espírita, sempre sob supervisão da doutrina. Desta feita, Alírio e Divaldo seguem propagando os comandos criados pelo dispositivo da sexualidade, então, é homossexual? Case-se, constitua família, compre uma casa, viva uma união estável, criem laços afetivos, mas que não sejam necessariamente laços sexuais, o amor sublimado.

Os discursos analisados direcionam o sujeito homossexual para uma normalidade, "normalidade" essa que ele busca na tentativa de ser aceito e agregado a teia social. Nossa sociedade normatizadora, fazendo uso do dispositivo do saber-poder-prazer, aproveita, segundo Foucault (2015), da busca dos homossexuais pelos direitos sexuais para controlá-los, quando a busca deveria ser "para reivindicar formas de cultura, de discurso, de linguagem etc" (FOUCAULT, 2015, p. 395). O problema dos homossexuais estaria no fato de reduzirem tudo ao sexo, segundo Foucault.

O homossexual ainda é visto como um sujeito perigoso, que não se enquadra na lógica binária homem/mulher, macho/fêmea, colocando em risco os códigos morais (Foucault, 2017) estabelecidos, sendo assim, deve-se resguardar.

Por fim, devemos ressaltar que, a homossexualidade não pode ser vista, na doutrina proposta por Divaldo Franco, como uma transgressão a conduta moral. Devemos esclarecer que ser homossexual na Doutrina Espírita é algo normal, o erro existe na prática sexual, ou no homossexualismo como reforça Alírio de Cerqueira Filho. A sublimação é a saída mais acertada para que a evolução moral e espiritual ocorra. Essa lógica diverge das demais religiôes que se dizem cristâs, é um avanço considerável, mas reforça o estereótipo em relação ao homem gay, de que ele é um ser sexualizado e de que tudo se resume ao sexo.

O discurso proferido não rompe com os binarismos, os conceitos cristãos adaptados, reinterpretados e contidos na doutrina espírita, se ancoram no heterossexismo onde se pauta, orientando as identidades e as representaçóes coletivas que devem gerir as relaçóes sociais dentro da religiáo, ou dentro do espaço público religioso, ainda, a partir de uma lógica patriarcal, se percebe claramente que os discursos são orientados pelo modelo heterossexual ancorado na lógica reprodutiva, familiar e religiosa. A partir das análises, no que se refere as obras investigadas, percebemos a doutrina espírita como um dispositivo normativo, dotado de múltiplas estratégias de produçáo de sujeitos normalizados. 


\section{REFERÊNCIAS}

AMORIM, P. P. "ROUSTAING: A CISÃO NO INTERIOR DA FEDERAÇÃO ESPÍRITA BRASILEIRA (1920 - 1922).” Revista Brasileira de História das Religióes. Maringá (PR) v. III, n.9, jan/2011. ISSN 1983-2859

AMORIM, P. P. Muito além da unidade: a cisão no movimento espírita. In: AMORIM. (Org.). Muito além da unidade: a cisão no movimento espírita. 1ed.São Paulo: UNESP, 2012, v. p. 119-138.

ARRIBAS, Célia da Graça. Autoridades espíritas: critérios para tipologias e repartiçôes das lideranças no espiritismo. In: SOUZA, André Ricardo de. Etal (org) Espiritualidade e espiritismo: Reflexōes para além da religiosidade. Porto de Ideias. São Paulo. 2017

BRASIL. Instituto Brasileiro de Geografia e Estatística. Censo Demográfico e Populacional Brasileiro de 2010.

BORRILLO, Daniel. Homofobia: História e Crítica de um preconceito. Autêntica Editora. Belo Horizonte. 2015.

FOUCUALT, Michel. História da Sexualidade. Vol. 1, 2014. Vol. 2, 2014. Vol. 3, 2017. Paz e Terra. Rio de Janeiro/São Paulo.

FOUCUALT, Michel. Os Anormais. Curso no Collège de France (1974-1974). Martins Fontes. São Paulo. 2001.

MISKOLCI, Richard. Desejos Digitais. Uma análise sociológica da busca por parceiros on-line. Belo Horizonte. Autêntica. 2017.

NATIVIDADES, Marcelo. Homossexualidade Masculina e Experiência Religiosa Pentecostal in Sexualidade, Família e Ethos Religioso. Garamond Editora. 2005.

NATIVIDADE, Marcelo Tavares. Deus me aceita como eu sou? A disputa sobre o significado da homossexualidade entre evangélicos no Brasil. Tese (Doutorado em Sociologia e Antropologia) - Universidade Federal do Rio de Janeiro, Instituto de Filosofia e Ciências Sociais, Rio de Janeiro. 2008.

ORLANDI, Eni Puccinelli. As Formas do Silêncio: no movimento dos sentidos. Editora da Unicamp. Campinas. 2007.

PEREIRA, Francisco Jomário. "TRANSAR PODE, MAS VOCÊ NÃO DEVERIA”: A Representação da Homossexualidade no Discurso Espírita Brasileiro. Tese de Doutorado em Sociologia- Universidade Federal da Paraíba. João Pessoa. 2020.

SOUZA, André Ricardo de. A livre religiosidade e a compulsória ciência do sociólogo da religião. Contemporânea - Revista de Sociologia da UFSCar, v. 5, n. 2, jul.-dez. 2015, pp. 289-325. 


\section{OBRAS ANALISADAS}

FEB, Federação Espírita Brasileira. < http://www.febeditora.com.br/quem-somos/> acessado em 03 de janeiro de 2019.

Mediunidade: Tipos de psicografia. <https:/www.febnet.org.br/wp-content/uploads/2012/06/ Modulo-2-Tema-5-Psicofonia-e-psicografia.pdf.> Acessado em 03 de janeiro de 2019.

FEBP, Federação Espírita Paraibana < http://www.fepb.org.br/estrutura-funcional/centrosespiritas/?cidade=Campina+Grande+PB\&bairro=Todos+os+bairros $>$. Acessado em: 20 de março de 2019.

KARDEC, Allan. O Evangelho Segundo o Espiritismo. Editora Petit. 1997.

O Livro dos Espíritos. Editora Petit. 1997.

O Livro dos Médiuns. Editora Petit. 1997.

LOPES, Luiz Fernando (org). Amor e Sexualidade: A conquista da Alma. Editora Leal. Salvador. 2018.

Sexo e Consciência. Editora Leal. Salvador. 2016

MANOEL (Espírito). Sexo e Obsessão. Psicografado por Divaldo Pereira Franco. Editora Leal. Salvador. 2002.

MENEZES, Bezerra. União dos spiritas. Revista O Reformador. Rio de Janeiro. V. 14. N. 32. Agosto. 1896.

SAEGUSA, Claudia (org). Divaldo Franco Responde. Vol. 2. InteLítera, São Paulo. 2013.

STOLL, Sandra Jacqueline. Espiritismo à Brasileira. São Paulo, Edusp/Orion, 2003.

"Narrativas Biográficas: a Construção da Identidade Espírita no Brasil e sua Fragmentação", in Estudos Avançados 18, 2004, p. 52. 